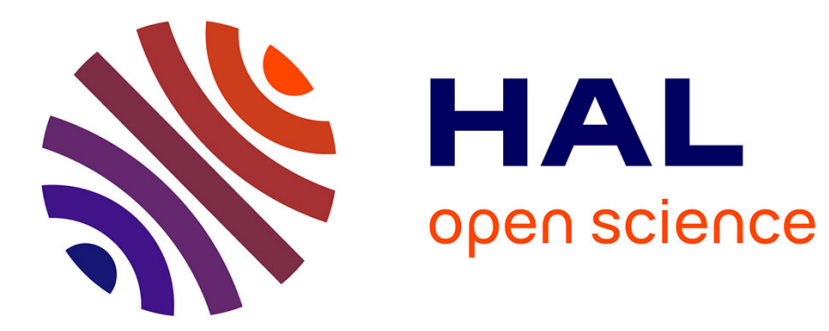

\title{
Towards Organizational Democracy? Convergence and Divergence in Models of Economic and Political Governance
}

\author{
Emmanuelle Avril, Christine Zumello
}

\section{- To cite this version:}

Emmanuelle Avril, Christine Zumello. Towards Organizational Democracy? Convergence and Divergence in Models of Economic and Political Governance. New Technologies, Organizational Change and Governance, Palgrave Macmillan, 2013, 1137264225. 10.1057/9781137264237_1 . hal-01377228

\section{HAL Id: hal-01377228 \\ https://hal.science/hal-01377228}

Submitted on 8 Oct 2016

HAL is a multi-disciplinary open access archive for the deposit and dissemination of scientific research documents, whether they are published or not. The documents may come from teaching and research institutions in France or abroad, or from public or private research centers.
L'archive ouverte pluridisciplinaire HAL, est destinée au dépôt et à la diffusion de documents scientifiques de niveau recherche, publiés ou non, émanant des établissements d'enseignement et de recherche français ou étrangers, des laboratoires publics ou privés. 


\title{
Introduction: Towards
} Organizational Democracy? Convergence and Divergence in Models of Economic and Political Governance

\author{
Emmanuelle Avril and Christine Zumello
}

This study on organizational change begins with the idea that globalization and the development of the new information and communication technologies (ICTs) have favoured the structural convergence of organizations, resulting in the hegemonic dominance of business values and practices in virtually all types of organizations, notably political parties and public or semi-public organizations. So far, very few scholars have tried to make this convergence between business organization paradigms and those present in other types of organizations, notably political parties, semi-public bodies and non-governmental organizations (NGOs), explicit, with the notable exception of Max Weber, who pointed out in his 1925 book Economy and Society the continuities of structure and practice deriving from the bureaucratic form present within all large-scale organizations (Weber, 1978), and Robert Michels, who highlighted in 1911, through his theory of the 'Iron law of oligarchy', the process of bureaucratization of political parties (Michels, 1915).

Although internal tensions between different organizational models have inevitably manifested themselves, particularly through the resistance of those actors whose traditional significance and influence came to be eroded by the adoption of new processes and tools, the business 'model' has come to be regarded as a benchmark to be emulated by all organizations, in a quest for greater adaptability, efficiency, and competitiveness, often shrouded in a democratizing discourse. However, 


\section{PROOF}

2 Introduction

the succession of bubbles and, since 2008, the global financial collapse have brought the so-called business 'model' into disrepute and given greater importance and credibility to alternative organizational models which claim to reflect truly democratic principles. This has allowed for the emergence of a renewed and much more explicit debate on organizational design within organizations, between advocates of competing organizational models: organizational issues may even take precedence over goals and tactics.

The objective of this book is dual: first, it aims to confront the overarching rhetoric of democratization - born out of the new governance apparatus which emerged out of the recent environmental changes with the empirical effects of the new practices on decision-making structures. What are the practical manifestations of the replacement of the old insular hierarchical organizational model with participative horizontal structures? Has the new paradigm really displaced the old? Second, this book aims at assessing the future evolution of organizational models, whether through a revival of traditional and supposedly more democratic forms or through the development of alternative models breaking away from a dominant 'model' which many now consider to have failed.

\section{What is an 'organization'? Definitions and methodology}

'Organization' is a generic term which describes a variety of different aggregations of people and structures with a final goal. An organization's structure is the framework whereby the final desired goal can be achieved. This structure is made up of a range of components, including complexity, formalization, and centralization. The degree of complexity is set out right at the beginning on the number of aims the organization has; formalization relates to the number of rules an organization has and its reliance on these rules and procedures to direct behaviour; centralization is a way in which to analyse where the decision-making powers within an organization develop from (Hall and Tolbert, 2008). Some organizations choose to be highly centralized, where most decisions are made at the highest level of management and orders flow down to other members. In a decentralized organization, the authority to make decisions is more widespread to all levels. It should be noted that the centralized and decentralized forms are extremes and that organizations employ a variety of these forms at different levels, and even combine elements of both. Other factors exist which can affect organizational structures, such as the organization's external environment. Factors beyond the organization's control (price fluctuations, laws, etc.) affect 


\section{PROOF}

Emmanuelle Avril and Christine Zumello 3

its performance, so changes may be needed within the organizational structure in order for the organization to survive.

This thrust for change can originate from a variety of sources, insofar as large-scale organizational changes are influenced by factors as diverse as downsizing workforces, the globalization of markets, the flattening of hierarchies or the influence of new information technologies (Harvey and Brown, 1996: 90), in particular what has been called Web 2.0, the second-generation Web-based communities where users can generate and distribute the content. But the champions of change have to pay attention to the potential for resistance within organizations (Burnes, 1996), a phenomenon which may be preempted through the creation of a climate conducive to change, where change is accepted as the norm. Indeed, the more transformational the change, the more imperative it becomes that the organization's culture also changes, or large-scale organizational transformations will be resisted. Organizations therefore strive to create an atmosphere conducive to change among their employees or members, although most change management theorists agree that cultural change is particularly difficult to achieve (Miller, 1998: 375). Paradoxically, though, an organization's culture is that which might protect it from significant changes that would compromise its identity, both internally and externally.

Although specialists usually trace its roots back to Max Weber, organizational studies began as an academic discipline with the advent of scientific management in the 1890s, of which Taylorism represents the most striking manifestation. After the First World War the focus of organizational studies shifted to the 'human' dimension and to the study of how psychology affected organizations, an evolution partly triggered by the identification of the so-called Hawthorne Effect. This human relations movement, led by high-profile scholars such as Abraham Maslow, David McClelland, and Victor Vroom, focused on motivation and the actualization of the individuals' goals within the organization. The field shifted even further after the Second World War, when the invention of large-scale logistics and operations research led to a renewed interest in rationalist approaches, together with a growing interest in scientific theories and methods, as illustrated by the 'Carnegie school' of organizational behaviour, whose main proponents, Richard Cyert and James G. March, championed a decision-centred view of organizations (Cyert and March, 1963). The field was strongly influenced by social psychology as illustrated by the development, for example, of the 'bounded rationality' theory by Herbert Alexander Simon, whose aim was to challenge the comprehensive rational model used in economics. This theory

February 22, 2013 11:28 MAC/AVRIL Page-3 9781137264220_02_cha01 


\section{PROOF}

4 Introduction

recognized that it is impossible to comprehend all of the potentially relevant information in making choices. It is worth pointing out that this notion originated in political science and that Simon himself was at the crossroads of political science, economics, psychology, and computer science (Simon, 1947, 1979, 1995). Starting in the 1980s, cultural explanations of organizations and change also became an important area of study, with qualitative methods, informed by anthropology, psychology, and sociology, becoming more acceptable.

As a result, if we take a classic definition of organization which sees it as 'a structured social system consisting of groups of individuals working together to meet some agreed-on objectives' (Greenberg and Baron, 2003), what we notice is that the key elements of this definition (individuals, groups, social systems, and objectives) are not confined to a single analytical model but relate instead to a wide range of disciplines such as psychology, sociology, economics, anthropology, political science, and management. As for organization theory, this draws on the sciences, the humanities, and the arts, and so presents the intellectual challenge of thinking in interdisciplinary ways. In this respect, British sociologist Gibson Burrell and British organization theorist Gareth Morgan were among the first to draw attention to the multiple perspectives of organization theory, arguing that knowledge is based on different paradigms, each with its own assumptions about the world (Burrell and Morgan, 1979). It follows that organizational studies, as illustrated by the analyses contained in this volume, draw from a variety of methods, including the quantitative methods found in other social sciences, as well as qualitative methods, such as ethnography and case analysis. In recent years, 'systems thinking' has been developed to provide techniques for studying systems in holistic ways to complement traditional reductionist methods. The systems framework (an early exponent of which was Alexander Bogdanov, who sought to identify the organizational principles that underlie all systems [Bogdanov, 1980]) also transcends the perspectives of individual disciplines. Drawn from physical and engineering models, systems theory considers organizations as systems which must adapt to environmental changes in order to survive, an approach made popular with the advance in information technology which sees organizations changing in line with new technical possibilities. Yet organizations cannot be viewed simply as communications networks, and such an approach overlooks the human dimension. A fruitful dialogue can therefore be established across disciplines, which highlights the increasing structural convergence of various types of organizations as well as the convergence of both the discourses on internal 


\section{PROOF}

Emmanuelle Avril and Christine Zumello 5

reform and the tools employed to bring about a perceived improvement in the efficiency of processes.

Our perspective seeks to establish a parallel in organizational changes within organizations which are not usually thought of as similar. We show that both economic organizations and businesses, political parties and public organizations have undergone similar transformations due to several factors, both internal and external, which have led to a re-composition of organizational barycentres. The studies collected in this volume share an underlying concern to return to the organizational level of analysis which seems to be have been lost, or at least overlooked, in recent years.

\section{Governance and organizational structure}

As Gerald Davis has shown, corporate governance was mainly confined to law and business schools before the 1990s and has, since then, become a ubiquitous concept (Davis, 2009: 32-57). Governance addresses the question of the distribution of power within an organization, whether public or private. If one adopts this definition then one needs to identify the whole range of participants in an organization. The participants, also known as stakeholders, need to be recognized as constituents of the organization. From that perspective, recent changes have definitely provided some stakeholders with a stronger input and thus have affected the structure of the organization itself. Among those changes, one needs to stress the growth of markets or rather the growth of reliance on markets for both businesses and political parties. Under the Efficient Market Hypothesis (EMH) the power of prediction of markets became the major reference and thus informed the 'new managerialism'. Corporations would thus be reshaped around the fleeting trends of the market. Karen Ho refers to the 'liquidation' of corporations (Ho, 2009): under the diktats of short-termism and immediate performance, the boundaries of organizations have been 'liquefied'. The organizational structure is no longer rigid and set; it needs to be constantly adapted. Similarly, with the technical and communication revolution of Web 2.0, stakeholders, whether they are party members, voters, or clients, can almost instantly send signals to the organization, which both needs to pay attention to those signals and, in turn, tries to re-establish a top-down form of management in which ICTs are used to shape the needs of its constituents, members, or clients. In such a case we would then resort to a common and well-established trend of advertisers and marketers: create a need. This book will look at the ways 


\section{PROOF}

6 Introduction

in which ICTs are used by economic organizations and political parties alike to shape their stakeholder base.

The concept of governance has been explored in many academic fields, including political science, public administration, policy-making, planning, and sociology (Rosenau and Czempiel, 1992; Kooiman, 1993; March and Olsen, 1995; Peters, 1996; Rhodes, 1996). While government refers to the planning and implementation of activities backed by those with legally and formally derived authority and policing power, governance refers to the planning and implementation of activities backed by the shared goals of citizens and organizations, who may or may not have formal authority and policing power. As an activity, governance seeks to share power in decision-making, encourage autonomy and independence in citizens, and provide a process for developing the 'common good' through civic engagement.

One noticeable evolution is that the frontiers between different types of organizations have become increasingly porous. An interesting aspect of the new governance of public administration is that it is characterized by increased collaboration among private, public, and non-profit organizations. Thus there is a need for researchers to describe and analyse these new models of governance and help understand their impact on both citizens and traditional democratic institutions. As pointed out above, technological change also plays an important part in setting out a specific context: Helen Margetts and Patrick Dunleavy, among others, have striven to identify the specific elements of the so-called digital-era governance (Dunleavy et al., 2006). The purpose of this book, however, is to focus on issues of internal governance rather than those related to external controls, although external governance, or the way democracy is regulated in a given country, obviously has an impact on the way organizations in a given context operate internally (Norris, 2004; Janda, 2005; Scarrow, 2005). We therefore take the concept of governance as referring to the internal structure, organization, and management of autonomous institutions.

\section{Democracy and governance}

The focus on the need to change is best reflected in the widespread organism metaphor, which has come to replace the machine metaphor prevalent in the age of scientific management and encapsulates the notion that an organization which fails to evolve and adapt is doomed to extinction (Morgan, 1986). The evolutionary and biological metaphor emphasizes the survival of the organization as a key aim 


\section{PROOF}

Emmanuelle Avril and Christine Zumello 7

and places greater emphasis on the relation between the organization and its environment. This has resulted in the emergence of an ethos of change in all types of organizations - change becoming a cardinal value irrespective of its actual effects on the efficiency of processes and regardless of the human cost attached to the changes. This book seeks to uncover the hidden rationale behind change practices in various types of organizations to highlight the ascent of an ideology of change which carries with it the notion of the inevitability of change and a concomitant disregard for the impact of human activity. Since change is often justified in the name of modernization and democratization, a model set against the much maligned bureaucratic model, a close look at the actual effects of change on decision-making processes is called for.

Here again, information technologies affect business and organizational processes at all levels. Neil Washbourne has stressed the democratizing influence of new technologies on organizations, which are seen to weaken oligarchy and institutionalization and promote decentralized modes of behaviour (Washbourne, 2001). However, this assumption again needs to be set against the actual effects of the adoption of electronic processes, which often tend, on the contrary, to increase standardization. Rachel Gibson and Stephen Ward question the extent to which ICTs are really able to override existing processes, stressing that 'simply providing electronic tools is not the same as empowering members' (Gibson and Ward, 2009: 31). Indeed, in many cases the widening of participation rights for members has paradoxically not come with an increased accountability of leaders or more democratic processes. We must therefore refrain from taking a mechanistic approach linking ICTs with increased internal democracy and instead look closely at some of the sometimes unintended effects of the new processes. Matthew Hindman also has questioned the myth of 'digital democracy', contending that although the channels of expression have been greatly expanded by the versatility of the new technical possibilities of Web 2.0, the actual 'democratising' forces underlining this change are not necessarily present. He shows that the working and launching of new Web 2.0 devices can follow 'old organizational patterns' akin to a hierarchical type of organization in which a small group of informed users/insiders controls the flow of information. In this new type of information flow, the 'middle is missing' (Hindman, 2009: 129) and thus the proclaimed democratizing effect of ICTs may not stand the reality test, for example, of online organizing for political campaigns. Peter Shane has warned against the 'extravagant expectations about information technology on governance and democracy' (Shane, 2004: 155). 


\section{PROOF}

8 Introduction

It must be stressed that expectations differ from one type of organization to the next. Political parties, which seek to take control of the state, are, in liberal democracies, keen to present themselves as internally democratic, especially left-wing parties that have traditionally placed a strong emphasis on equality. Corporations, on the other hand, which are profit-seeking organizations, may not have always faced such requirements, whereas NGOs, insofar as they represent civil society, have tended to be expected to behave as microcosms of democracy. This is the reason why the confrontation and comparison of practices within a range of organizations is so fruitful, against this general backdrop of the deliberative imperative, which can be said to stand, in liberal democracies, as the current dominant theoretical model.

\section{Changing models}

Traditional organizations integrate work vertically, delegating authority in a pyramidal, hierarchical structure, an organizational form first developed in the United States in the late 19th century with the advent of mass production, and theorized by the renowned industrial engineer Frederick Winslow Taylor (1911). The hierarchical structure was designed and best suited to manage complex processes such as automobile assembly where production could be broken down into a series of steps. Hierarchical corporations typically managed all the activities of a business so that a centralized managerial hierarchy controlled the entire production process. Although effective for managing large numbers of workers, such structures lacked agility. Since the 1980s, many organizations have flattened their structures by shifting authority downwards, giving employees or members increased autonomy and decision-making power. Advantages of flatter organization forms include a decreased need for supervisors and middle management and the ability to process information faster because of the reduced number of layers in the organization. Flat organizations opting for joint ventures and strategic alliances show increased flexibility and innovation and replace many traditional hierarchies. Ray Grenier and George Metes discuss the shift to this new organizational structure as a response to unprecedented customer expectations and alternatives, global competition, time compression, complexity, rapid change, and increased use of technology (Grenier and Metes, 1995).

In this new environment, organizations create ad hoc alliances with groups and individuals from different organizations to build a specific product or service over a short period of time. Since products 


\section{PROOF}

Emmanuelle Avril and Christine Zumello 9

and services are not produced in a single corporation whose purpose is longevity, these alliances are regarded as 'virtual'. William Davidow and Michael Malone (1992) claim that this new model is central to the new business revolution. The concept of the 'virtual' corporation they put forward brings a range of innovations together, such as flexible manufacturing, worker empowerment, organizational streamlining, and mass customization. In a virtual organization, interfaces between company, supplier, and customers continuously change, resulting in a blurring of traditional functions. The virtual organization may not have a central office or an organizational chart; computerized information systems allow employees from geographically dispersed locations to link up with one another; the virtual office may use desktop videoconferencing, collaborative software, and intranet systems to enhance the flow of information among team members. Besides the need for instantaneous communication with one another, members of these virtual teams have increasing requirements as regards the amount and quality of information they need to do their work. Firms today are much more dependent on one another than they have been in the past, which requires unprecedented levels of trust. These strong interdependencies cause organizations' boundaries to be blurred as competitors, suppliers, and customers enter into cooperative agreements. In an environment characterized by increased volatility, organizations have needed to become even more flexible and agile and to bring products and services to market at an increasing rapid pace, a pace which traditional organizational forms no longer seem capable of sustaining.

Organizational change tends to be seen from the perspective of facilitating change, identifying obstacles to change, and fostering a culture of change; in other words, exclusively as a management issue, from the point of view of business leaders and the consultants advising them rather than from the perspective of grassroots members. We seek to redress this in part by focussing on the way in which new processes affect the practice of the organizations' members. We also seek to address the existing gap in the contemporary literature between a range of organizations. Even though among practitioners the permeation between business values and tools and political organizations already exists, as seen, for example, in the emergence of political marketing as a field of study (Lees-Marshment, 2001, 2004) as well as the concept of the 'political consumer' found in the work of Margaret Scammell (1999, 2003), we consider that an attempt to explicitly join the dots is a timely enterprise. The aim of this book is to look at the impact of reforms on 


\section{PROOF}

10 Introduction

different kinds of organizations and assess the intended and unintended outcomes of the adoption of new governance models on the functioning and performance of organizations.

\section{Key concepts: responsiveness and empowerment}

The book revolves around two major components of governance which have in turn informed the evolution of organizational structures: responsiveness and empowerment (See Illustration 1.1). Although these concepts, just as the very notion of 'organizational democracy' itself, have been largely taken over by business consultancies, instrumentalized and sometimes bandied about as miracle management tools, we restore them, in this volume, to their full original meaning.

At the first level, organizational responsiveness is usually understood as the adaptation to the changing environment. In times of increased competition and continuously evolving customer needs, responsiveness to environmental change is considered as a vital success factor for organizations. At the most basic level of interpretation, organizational responsiveness represents the ability of an organization to respond appropriately to its external environment (Clippinger, 1999). The environmental dimension is of great importance as contemporary organizational environments have become more complex, and today's organizations have become too interconnected and too complex to be managed by traditional top-down and hierarchical means, thus requiring new organizational strategies that make use of new standards and values capable of creating highly adaptable organizations.

While the wider environmental meaning of responsiveness is fully relevant to the analyses presented in this volume, we take a more specific meaning of the concept as responsiveness to the stakeholders. In short, from a stakeholder perspective, an organization, whether it is for-profit or non-profit, public or private, can be seen as a network of groups and individuals who choose to cooperate to achieve desired outcomes. Therefore, anyone with an investment in the organization's success can be defined as a stakeholder (Freeman, 1984; Friedman and Miles, 2001). The role of governance in organizations is to ensure that the maximum possible value is generated by the organization for the benefit of all stakeholders. Organizations also benefit when the active and positive participation of all stakeholders is achieved. Stakeholders, who have an investment in the organization which may be financial or non-financial in nature, can claim a right to representation and to participate in organizational decision-making. 


\section{PROOF}

Emmanuelle Avril and Christine Zumello

11

A key aspect of responsiveness is that it is not strictly determined by the nature of environmental changes, but rather is influenced by other organizational factors that can either foster or inhibit actions. A crucial factor which has been emphasized in contemporary analyses is the importance of knowledge availability and exchange within organizations. In today's global and fast-changing environment, responsive practices tend to be those which can be developed in a collaborative fashion (Alavi and Leidner, 2001). In particular, organizational flexibility, which makes the organization more responsive to change, is what enables organizations to face environmental fluctuations. The term organizational flexibility refers to the overall flexibility of an organization in terms of resources and processes, thanks to the use of the Internet and digital technologies. In response to new competitive pressures, organizations adopt new information technology tools to improve processes, streamline operations, and cut costs, so that the impact of information technology permeates the entire organization: structure, process, and marketing methodology are all affected by the introduction of information technology.

Overall, among the elements which can increase responsiveness and are closely related to new technological tools are decentralized decision-making, improved collaboration, distributed intelligence, dispersed learning processes, as well as the opportunity for employees or members within an organization to use knowledge in order to adapt their actions to appropriately fit the environment. As a way to promote transparency and access in decision-making processes, whether in economic organizations, political parties, or public or semi-public organizations, responsiveness to the stakeholders has thus become a key measure of 'performance' and 'adaptability'.

The second leading thread of the book is the issue of empowerment in the governance of organizations and the way the new communication tools have - or have not - impacted political and business organizations under the impetus of a 'democratic urge' or 'democratic claim'. The need for flexibility and responsiveness leads to the decentralization of decision-making authority in organizations. Under conditions of uncertainty and complexity, the organization must design its structures and processes to be flexible and responsive to changes in customer desires, technology, governmental regulations, and economic conditions. More emphasis is placed on individual and group control than on managerial and hierarchical control. By emphasizing initiative, direct interaction, open communication, and the creation of teams composed of various members of the organization, organic 


\section{PROOF}

organizations, as opposed to top-down structures, are able to utilize their internal diversity to foster innovative responses to environmental challenges.

Empowerment, although widely used, remains a theoretical concept whose definitions are extremely varied (Conger and Kanungo, 1988). The first difficulty lies in the fact that the term is a linguistic short cut. Indeed, for the lack of a clear conceptual framework, empowerment has often been likened to several peripheral and important - but different - concepts. Among others, empowerment has been associated with 'power-sharing', 'delegation of power', 'ending oppression of minority groups', and 'motivation' to describe a process whereby power does not just move from one group to the other but in which the overall amount of power increases, in what can be best described as a positive sum game (Pranic and Roehl, 2012). In this case the group of empowered people, be they political party activists, party members, company employees, or more generally company stakeholders, does not gain power over another group but becomes empowered alongside the other groups in the organization. In this particular respect, we intend to show in this book that ICTs are a facilitator in the empowering process of each constituent of an organization.

Empowerment is also a concept which is used across various disciplines from psychology to social studies, political science, and management. A unifying thread in the 'empowerment approach' of organizational design is its embedded democratic potential. Gretchen Spreitzer, in a comprehensive review of the literature on empowerment at work, draws from Rosabeth Moss Kanter's (1977) classic of empowerment in the workplace, Men and Women of the Corporation, to show that the social-structural perspective of empowerment is 'embedded in the values and ideas of democracy' (Spreitzer, 2007: 55). Organizations willing to foster employee participation are able to transform their organizational processes and structures 'away from top-down control systems' in order to adopt 'high involvement practices where power, knowledge, information and rewards are shared with employees in the lower echelons of the organizational hierarchy' (Ibid.). Thus members at low levels of the organizational hierarchy can be empowered provided they are given access to the necessary information and resources, which requires participative decision-making, flat organizational structures, and an open flow of information.

The concept of empowerment, with its emphasis on direct access, is considered to be a key element of the learning organization as it may contribute to 'unlock the energy and talent that reside within an 


\section{PROOF}

organization' and, as such, is 'at the heart of competitiveness' (Mishra and Bhaskar, 2010: 52). The chapters in this book also concur in establishing the extent to which participation in decision-making and in the life of political or economic organizations is improved, modified, enriched, or, on the contrary, deteriorated when relying on new technology. Some contributions clearly show that the expectations of Web 2.0 do have empowering potential which, in some cases, did not live up to its promises. We rely on the four cognitive dimensions expounded by Spreitzer (1995), namely meaning, competence, self-determination, and impact.

Long-term studies of empowerment-oriented practices have demonstrated their growth in the last two decades (Lawler et al., 2001). Today, most organizations have adopted some kind of empowerment initiative for some of their workforce or membership, in an attempt to overcome the perceived harmful effects of traditional bureaucracies through the creation of high-involvement organizations. Empowerment, which enables employees or members to take part in decision-making, is seen as a way to help them break out of passive mindsets and to embrace new ideas. Empowerment has thus become a ubiquitous management tool, especially in virtual settings where team members do not have face-to-face interactions. Even though in the business world studies indicate that the move towards empowerment structures have been mainly intertwined with issues of productivity rather than welfare, the fact remains that, in any organization, the success of an empowerment strategy will depend on the ability of managers to reconcile the loss of control inherent in the sharing of power with the need to empower employees to achieve strategic goals (Mills and Ungson, 2003).

Most importantly for this volume, empowerment is viewed as critical in the process of organizational change. Empowerment has significant implications for understanding change processes. Rather than forcing or pushing people to change, empowerment provides a mechanism for getting them to want to change because they now have the ownership of the change process (Weick and Quinn, 1999). Because of the pressures faced by modern organizations, the promotion of empowerment practices and structures appears poised to have a profound and lasting effect on the evolution of organizations and the role of the individual within them. However, many leaders have a fundamental misunderstanding of how people can be empowered and many organizational theorists agree that feeling empowered is not the same as being empowered (Jacques, 1996). In fact, many empowerment schemes have been implemented 


\section{PROOF}

14 Introduction

New Technology, Organizational Change and Governance

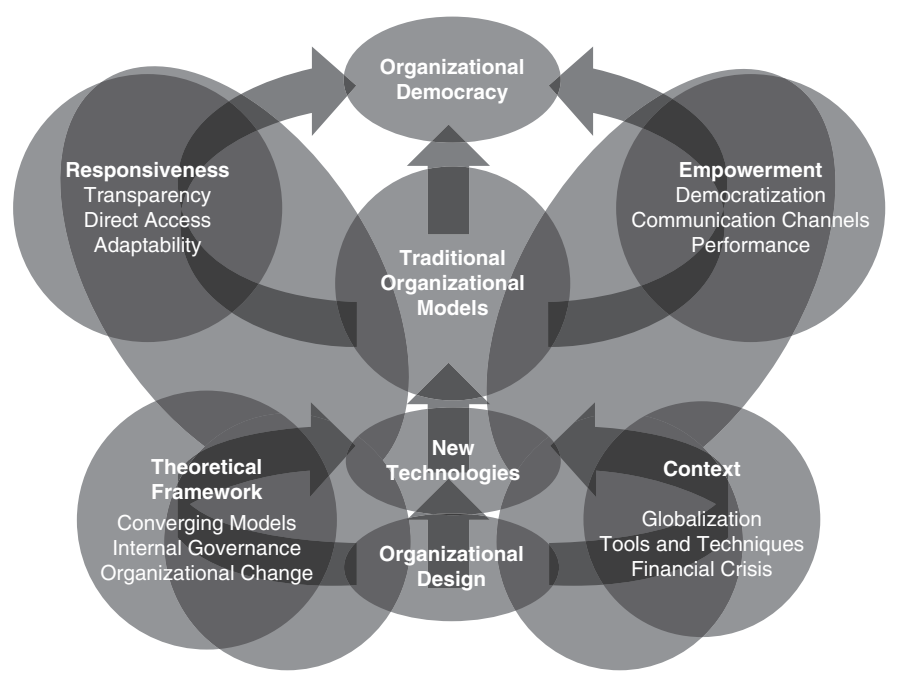

Illustration 1.1 Book overview

in ways that are more likely to disempower, rather than empower, the organization's members.

The diagram above illustrates the way the two concepts of responsiveness and empowerment bind the chapters together in a narrative of organizational change. What all the chapters in this volume have in common is that they address issues of adaptation of organizational structures to environmental and technological pressure, offer an evaluation of the quality of the processes put in place to increase the organization's ability to follow the stakeholders' cue, and provide an interpretation of the impact of the democratization forces at work. However, the emphasis and overall interpretation will differ from chapter to chapter so that a dialogue emerges between the various authors. As a result, the chapters fall under three sections to reflect the change in focus.

The first part, entitled New Paths of Governance, includes chapters which place greater emphasis on the contextualization of organizational democratization and the emergence or convergence of hitherto distant value systems. Cécile Doustaly addresses the case of the English Arts' Council to bring to light the new preoccupations of public arts organization in England through the adoption of managerial practices 


\section{PROOF}

and digital era governance. Roseline Théron's study of London Transport offers a striking illustration of the permeation of public services by the practices and values of the private sector and the culture clash which results from the top-down changes. Christine Zumello's chapter assesses the transformative impact of digital participation on US political parties and financial organizations, which have become more versatile and open, with a view to establishing whether greater access had led to enhanced political participation and more efficient financial organizations. Vincent Michelot's contribution explores the evolution of the legal landscape of campaign financing in the United States and the emergence of a new polymorphous party system which may mark the end of traditional political organizations. The 2010 Citizens United Supreme Court decision and its 2012 progeny can be seen as an attempt on the part of the Court's majority to disempower voters and the Federal Government.

If better responsiveness, freedom of expression, internal democracy, and internal efficiency are touted in all these cases, the empirical assessments provided here tend to nuance this initial democratic justification.

The second part, entitled Breaking Organizational Boundaries, includes chapters in which emphasis is placed on structures and the increasingly conflicting polarities within organizations. The concepts of direct access, participation, and representation are weighed against the input of the new information technology in order to evaluate the reality of the democratization of organizations. Susan Scarrow highlights, in a comparative perspective, organizational 'opposites' between traditional party activists and those with looser ties to the party. Emmanuelle Avril's chapter examines the Labour Party's internal transformation, which rests both on a discourse of democratization and on a move towards a marketing organizational model, where the formal model of membership is replaced by a much looser 'Supporters' network, deemed to be more responsive to the electoral market. Nathalie Duclos analyses the Scottish National Party's use of information technology and interactive social media as a way of both targeting new voters and including a wider range of actors in order to assess whether the party's rhetoric of democracy and democratization is borne out by the evidence. James Morone explores the way in which the break-up of traditional media monopolies and the rise of new media in the United States have allowed new and extremist political groups to infiltrate traditional political organizations, thus subverting the political process. Geraldine Castel addresses the issue of Web 2.0 and communication in political parties in the United Kingdom and assesses the impact of such technology on the shaping 
of new party structures in a bid to challenge the commonly held view that the introduction of new technologies has marked the advent of a digital-age direct democracy at the expense of more traditional collective models of representative democracy.

The third and last section, Emerging Patterns of Organizational Design, includes those chapters which move beyond the convergence and divergence of old and new models and practices and discuss the possible emergence of new models, thus seeking to challenge the orthodoxies about organizational change which prevail in the business and political spheres. Whereas the traditional process of organizational design places strategy before structure, new trends may illustrate the emergence of a new model, in which the reverse is true. Régine Hollander, in her study of the impact of information technology in US financial markets, compares the proclaimed democratizing benefits that such new technology is supposed to carry with the opacity that accompanies high frequency trading. Jean-Baptiste Velut analyses the impact of new technologies on advocacy networks by looking at the case of Citizen Trade Campaign Network, showing that Web-based communication has transcended old organizational dichotomies. Toby Coop explores the supposed advent of the 'leaderless' organization, notably through the study of global protest movements such as Occupy the Street which strive to establish a new, inclusive, non-hierarchical decision-making model backed up by the new social media tools available. Jennifer Lees-Marshment's contribution shows that consultative approaches are set up by political parties in order to foster more creative, deliberative, and constructive forms of campaigning.

\section{Bibliography}

Alavi, M. and Leidner, D.E. (2001). 'Review: Knowledge Management and Knowledge Management Systems: Conceptual Foundations and Research Issues', MIS Quarterly, 25(1): 107-136.

Bartunek, J.M. and Spreitzer, G.M. (2006). 'The Interdisciplinary Career of a Popular Construct Used in Management: Empowerment in the Late 20th Century', Journal of Management Inquiry, 15(3): 255-273.

Bogdanov, A. (1980). Essays in Tektology: The General Science of Organization (translation George Gorelik), Seaside, CA: Intersystems Publications.

Burnes, B. (1996). Managing Change: A Strategic Approach to Organizational Dynamics, London: Pitman Publishing.

Burrell, G. and Morgan, G. (1979). Sociological Paradigms and Organizational Analysis, London: Heinemann.

Camarinha-Matos, L., Afsarmanesh, H., and Ollus, M. (eds.) (2005). Virtual Organizations: Systems and Practices, New York, NY: Springer. 
Cheng, J.L.C. and McKinley, W. (1983). 'Toward an Integration of Organization Research and Practice: A Contingency Study of Bureaucratic Control and Performance in Scientific Settings', Administrative Science Quarterly, 28(1): 85-100.

Clippinger, J.H. (1999). 'Order From the Bottom Up: Complex Adaptive Systems and Their Management', in Clippinger, J.H. (ed.), The Biology of Business: Decoding the Natural Laws of Enterprise, San Francisco, CA: Jossey-Bass, pp. 1-30.

Conger, J.A. and Kanungo, R.B. (1988). 'The Empowerment Process. Integrating Theory and Practice', Academy of Management Review, 13: 471-482.

Cooper, C. and Barlin, J. (eds.) (2007). The Handbook of Organizational Behavior, London: Sage.

Cyert, R.M. and March, J.G. (1963). A Behavioural Theory of the Firm, Oxford: Blackwell.

Davidow, W.H. and Malone, M.S. (1992). The Virtual Corporation: Structuring and Revitalizing the Corporation for the 21st Century, New York, NY: Harper Collins Publishers.

Davis, G.F. (2009). Managed by the Markets, New York, NY: Oxford University Press. Dunleavy, P., Margetts, H., et al. (2006). Digital Era Governance: IT Corporations, the State and E-Government, Oxford: Oxford University Press.

Fitzpatrick, W.M. and Burke, D.R. (2002). 'Virtual Venturing and Entry Barriers: Redefining the Strategic Landscape', SAM Advanced Management Journal, 66(4): 22-30.

Franke, U.J. (1999). 'The Virtual Web as a New Entrepreneurial Approach to Network Organizations', Entrepreneurship \& Regional Development, 11(3): 203-229.

Freeman, R.E. (1984). Strategic Management: A Stakeholder Approach, Boston, MA: Pitman.

Friedman, A.L. and Miles, S. (2001). 'Developing a Stakeholder Theory', Journal of Management and Studies, 39(1): 1-21.

Gauja, A. (2006). Enforcing Democracy? Towards a Regulatory Regime for the Implementation of Intra-Party Democracy, Democratic Audit of Australia 2006, Discussion Paper 14/06.

Gibson, R.K., Nixon, P., and Ward, S.J. (eds.) (2003). Political Parties and the Internet: Net Gain?, London: Routledge.

Gibson, R.K., Oates, S., Owen, D., and Gibson, R.K. (eds.) (2005). The Internet and Politics: Citizens, Voters and Activists, London: Routledge.

Gibson, R.K., Römmele, A., and Ward, S.J. (eds.) (2004). Electronic Democracy: Political Organizations, Mobilization and Participation Online, London: Routledge.

Gibson, R.K. and Ward, S.J. (2009). 'European Political Organization on the Internet. Mobilization, Participation, and Change', in Chadwick, A. and Howard, P.N. (eds.), Routledge Handbook of Internet Politics, London: Routledge, pp. 25-39.

Goodstein, J.D. (1994). 'Institutional Pressures and Strategic Responsiveness: Employer Involvement in Work-Family Issues', Academy of Management Journal, 37(2): 350-382.

Greenberg, J. and Baron, R.A. (2003). Behavior in Organizations: Understanding and Managing the Human Side of Work, Englewood Cliffs, NJ: Prentice Hall.

Grenier, R. and Metes, G. (1995). Going Virtual: Moving Your Organization into the 21st Century, Upper Saddle River, NJ: Prentice Hall.

Hall, R.H. and Tolbert, P.S. (2008). Organization: Structures, Processes, and Outcomes, Upper Saddle River, NJ: Prentice Hall. 
Harvey, D. and Brown, D.R. (1996). An Experiential Approach to Organization Development, Englewood Cliffs, NJ: Prentice-Hall.

Hindman, M. (2009). The Myth of Digital Democracy, Princeton, NJ: Princeton University Press.

Ho, K. (2009). Liquidated. An Ethnography of Wall Street, Durham, NC: Duke University Press.

Howard, P.N. (2006). New Media Campaigns and the Managed Citizen, Cambridge: Cambridge University Press.

Jacques, R. (1996). Manufacturing the Employee: Management Knowledge from the 9th to the 21st Centuries, London: Sage.

Janda, K. (2005). Adopting Party Law (Political Parties and Democracy in Theoretical Perspectives Series), Washington, DC: NDI.

Kanter, R.M. (1977). Men and Women of the Corporation, New York, NY: Basic Books.

Kirkman, B.L., Rosen, B., Tesluk, P.E., and Gibson, C.B. (2004). 'The Impact of Team Empowerment on Virtual Team Performance: The Moderating Role of Face-to-Face Interaction', Academy of Management Journal, 47(2): 175-192.

Kooiman, J. (1993). Modern Governance: New Government-Society Interactions, London: Sage.

Lawler, E.E., Mohrman, S.A., and Benson, G. (2001). Organizing for High Performance: Employee Involvement, TQM, Reengineering, and Knowledge Management in the Fortune 1000, San Francisco, CA: Jossey-Bass.

Lee, M. and Koh, J. (2001). 'Is Empowerment Really a New Concept?' International Journal of Human Resource Management, 12(4): 684-695.

Lees-Marshment, J. (2001). Political Marketing and British Political Parties: The Party's Just Begun, Manchester: Manchester University Press.

Lees-Marshment, J. (2004). The Political Marketing Revolution, Manchester: Manchester University Press.

Lincoln, N.D., Travers, C., Ackers, P., and Wilkinson, A. (2002). 'The Meaning of Empowerment. The Interdisciplinary Etymology of a New Management Concept', International Journal of Management Reviews, 4(3): 271-290.

Lipnack, J. and Stamps, J. (1997). Virtual Teams: Reaching Across Space, Time and Organizations with Technology, New York, NY: Wiley.

Locke, R.R. (1996). The Collapse of the American Management Mystique, Oxford: Oxford University Press.

Locke, R.R. and Spender, J.-C. (2011). Confronting Managerialism: How the Business Elite and Their Schools Threw Our Lives Out of Balance, London: Zed Books.

March, J.G. and Olsen, P. (1995). Democratic Governance, New York, NY: The Free Press.

McAuley, J., Duberley, J., and Johnson, P. (2007). Organization Theory: Challenges and Perspectives, Harlow: Prentice Hall.

McHugh, M., O'Brien, G., and Ramondt, J. (2001). 'Finding an Alternative to Bureaucratic Models of Organization in the Public Sector', Public Money \& Management, 21(1): 35-42.

Michels, R. (1915). Political Parties: A Sociological Study of the Oligarchical Tendencies of Modern Democracy (translation Eden Paul and Cedar Paul), New York, NY: The Free Press.

Miller, A. (1998). Strategic Management, Boston, MA: McGraw-Hill. 


\section{PROOF}

Emmanuelle Avril and Christine Zumello

Mills, P.K. and Ungson, G.R. (2003). 'Reassessing the Limits of Structural Empowerment: Organizational Constitution and Trust as Controls', Academy of Management Review, 28: 143-153.

Mishra, B. and Bhaskar, A.U. (2010). 'Empowerment: A Necessary Attribute of a Learning Organization?' Organizations and Markets in Emerging Economies, 1(2): 48-70.

Mitchell, T.R. (1978). People in Organizations. Understanding Their Behavior, Kogakusha: McGraw-Hill.

Morgan, G. (1986). Images of Organization, Newbury Park, CA: Sage.

Morgan, G. (1988). Riding the Waves of Change, San Francisco, CA: Jossey-Bass.

Morris, S.A. and McManus, D.J. (2002). 'Information Infrastructure Centrality in the Agile Organization', Information Systems Management, 19(4): 8-12.

Norris, P. (2004). Building Political Parties: Reforming Legal Regulations and Internal Rules, Stockholm: IDEA.

Pang, L. (2001). 'Understanding Virtual Organizations', Information Systems Control Journal, 6: 42-47.

Peters, B.G. (1996). The Future of Governing: Four Emerging Models, Lawrence, KS: University of Kansas Press.

Pranic, L. and Roehl, W. S. (2012). 'Rethinking Service Recovery: a Customer Empowerment (CE) Perspective', Journal of Business Economics and Management, 13(2): 242-260.

Rhodes, R.A.W. (1996). 'The New Governance: Governing without Government', Political Studies, 44(4): 652-667.

Robbins, S.P. (1987). Organization Theory: Structure Design and Applications, Englewood Cliffs, NJ: Prentice-Hall.

Rosenau, J.N. and Czempiel, E.O. (eds.) (1992). Governance without Government: Order and Change in World Politics, Cambridge: Cambridge University Press.

Scammell, M. (1999). 'Political Marketing: Lessons for Political Science', Political Studies, XLVII: 718-739.

Scammell, M. (2003). 'Citizen Consumers: Towards a New Marketing of Politics?' in Corner, J. and Pels, D. (eds.), Media and the Restyling of Politics: Consumerism, Celebrity, Cynicism, London: Sage, pp. 117-136.

Scarrow, S.E. (1996). Parties and Their Members, Oxford: Oxford University Press.

Scarrow, S.E. (2005). Implementing Intra-Party Democracy, Political Parties and Democracy in Theoretical Perspectives Series, Washington, DC: NDI.

Shane, P.M. (2004). Democracy Online. The Prospects for Renewal through the Internet, New York, NY: Routledge.

Simon, H.A. (1947). Administrative Behavior: A Study of Decision-Making Processes in Administrative Organizations, New York, NY: The Free Press.

Simon, H.A. (1979). 'Rational Decision-Making in Business Organizations', American Economic Review, 69: 495-501.

Simon, H.A. (1995). 'Rationality in Political Behavior', Political Psychology, 16: 45-61.

Spreitzer, G. (1995). 'Psychological Empowerment in the Workplace: Dimensions, Measurement, and Validation', Academy of Management Journal, 38(5): 1442-1465.

Spreitzer, G. (2007). 'Taking Stock: A Review of More than Twenty Years of Research on Empowerment at Work', in Cooper, C., and Barlin, J. (eds.), The Handbook of Organizational Behavior, Thousand Oaks, CA: Sage, pp. 54-72. 
Taylor, F.W. (1911). The Principles of Scientific Management, New York, NY: Harper. Tuten, T.L. (2010). Enterprise 2.0: How Technology, Ecommerce, and Web 2.0 Are Transforming Business Virtually, London: Praeger.

Vroom, V.H. and Jago, A.G. (1988). The New Leadership: Managing Participation in Organizations, Englewood-Cliffs, NJ: Prentice-Hall.

Washbourne, N. (2001). 'Information Technology and New Forms of Organising? Translocalism and Networks in Friends of the Earth', in Webster, F. (ed.), Culture and Politics in the Information Age: A New Politics?, London: Routledge, pp. $129-141$.

Weber, M. (1978). Economy and Society: An Outline of Interpretative Sociology (translation Guenther Roth and Claus Wittish), Berkeley, CA: University of California Press.

Weick, Karl E. (2001). Making Sense of the Organization, Oxford: Blackwell Business. Weick, K.E., and Quinn, R.E. (1999). 'Organizational Change and Development', Annual Review of Psychology, 50: 361-388.

Werther, W.B. (1999). 'Structure-Driven Strategy and Virtual Organization Design', Business Horizons, 42(2): 13-18. 